\title{
SUSCEPTIBILITY OF Cebus apella MONKEY (PRIMATES: CEBIDAE) TO EXPERIMENTAL Leishmania (L.) infantum chagasi-INFECTION
}

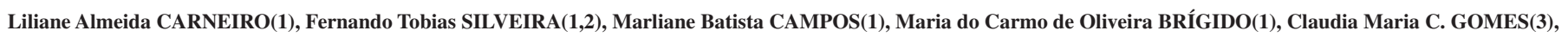
Carlos E.P. CORBETT(3) \& Márcia D. LAURENTI (3)

\begin{abstract}
SUMMARY
In Amazonian Brazil, the Cebus apella monkey (Primates: Cebidae) has been associated with the enzootic cycle of Leishmania (V.) shawi, a dermotropic parasite causing American cutaneous leishmaniasis (ACL). It has also been successfully used as animal model for studying cutaneous leishmaniasis. In this work, there has been investigated its susceptibility to experimental Leishmania (L.) infantum chagasi-infection, the etiologic agent of American visceral leishmaniasis (AVL). There were used ten C. apella specimens, eight adult and two young, four males and six females, all born and raised in captivity. Two experimental infection protocols were performed: i) six monkeys were inoculated, intra-dermal via (ID), into the base of the tail with $2 \times 10^{6}$ promastigotes forms from the stationary phase culture medium; ii) other four monkeys were inoculated with $3 \times 10^{7}$ amastigotes forms from the visceral infection of infected hamsters by two different via: a) two by intravenous via (IV) and, b) other two by intra-peritoneal via (IP). The parameters of infection evaluation included: a) clinical: physical exam of abdomen, weigh and body temperature; b) parasitological: needle aspiration of the bone-marrow for searching of amastigotes (Giemsa-stained smears) and promastigotes forms (culture medium); c) immunological: Indirect fluorescence antibody test (IFAT) and, Delayed-type hypersensitivity (DTH). In the six monkeys ID inoculated (promastigotes forms) all parameters of infection evaluation were negative during the 12 months period of follow-up. Among the four monkeys inoculated with amastigotes forms, two IV inoculated showed the parasite in the bone-marrow from the first toward to the sixth month p.i. and following that they cleared the infection, whereas the other two IP inoculated were totally negative. These four monkeys showed specific IgG-antibody response since the third month p.i. (IP: $1 / 80$ and IV: $1 / 320 \operatorname{IgG}$ ) toward to the $12^{\text {th }}$ month (IP: 1/160 and IV: 1/5120). The DTH-conversion occurred in only one IV inoculated monkey with a strong (30 mm) skin reaction. Considering these results, we do not encourage the use of $C$. apella monkey as animal model for studying the AVL.
\end{abstract}

KEYWORDS: Susceptibility; Cebus apella monkey; Experimental infection; Leishmania (L.) infantum chagasi.

\section{INTRODUCTION}

Actually, there are in Brazil eight well recognized Leishmania spp. belonging to the subgenera Viannia (L. braziliensis, L. guyanensis, $L$. lainsoni, L. shawi, L. lindenbergi and L. naiffi) and Leishmania ( $L$. amazonensis and L. infantum chagasi) which can give rise to clinical manifestations of human leishmaniasis. From these, L. (L.) i. chagasi has been regarded as the principal etiologic agent of American visceral leishmaniasis (AVL), whereas others are implicated as etiologic agents of different clinical forms of American cutaneous leishmaniasis (ACL) ${ }^{9,19,20}$.

The best way to prevent these forms of human leishmaniasis, either ACL or AVL, would be through the use of an efficient vaccine with capacity of developing human immune protection against these diseases. In this way, considering some ethical reasons which prohibit the use of humans in scientific assays with any health integrity risk, there has been encouragement for the development of animal models that can serve to study the pathology and/or immunology induced by these leishmanial parasites in humans. Thus, in viewing of the great physiologic and phylogenetic proximity between non-human primates with $\operatorname{man}^{1}$, there is significant amount of works either in the Old World or in the New World demonstrating that these animals may mimic the clinical-immunological manifestations found in human leishmaniasis ${ }^{17}$.

As examples on this issue, it should be regarded that some neotropical monkeys have prior been successfully used as experimental models for studying AVL, as following: Callithrix jacchus ${ }^{12}$, Aotus trivirgatus $\left(={\text { Aotus infulatus })^{4} \text { and Saimiri sciureus }}^{5}\right.$. In a similar way, the African green monkey Cercopithecus aethiops ${ }^{6}$ and the Presbytes entellus monkey ${ }^{14,15,16}$ have also been used for studying the Old World's visceral leishmaniasis.

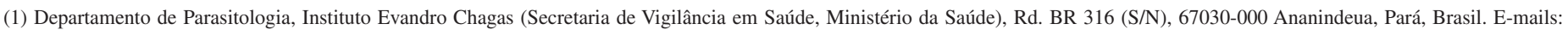
lilianecarneiro@iec.pa.gov.br; marlianecampos@iec.pa.gov.br; mcbrigido@yahoo.com.br

(2) Núcleo de Medicina Tropical, Universidade Federal do Pará (UFPa), Belém, Pará, Brasil. E-mail: fernandotobias@iec.pa.gov.br

(3) Departamento de Patologia, Faculdade de Medicina, Universidade de São Paulo (USP), São Paulo (SP), Brasil. E-mails: gomescla@usp.br; ccorbett@usp.br

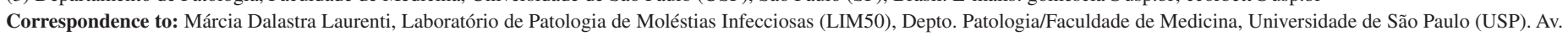
Dr. Arnaldo 455, $1^{\circ}$ andar, sala 1152, 01255-000 São Paulo, SP, Brasil. Phone/Fax: +55 11 3061-7426. E-mail: mdlauren@usp.br 
CARNEIRO, L.A.; SILVEIRA, F.T.; CAMPOS, M.B.; BRÍGIDO, M.C.O.; GOMES, C.M.C.; CORBETT, C.E.P. \& LAURENTI, M.D. - Susceptibility of Cebus apella monkey (Primates: Cebidae) to experimental Leishmania ( $L$. ) infantum chagasi-infection. Rev. Inst. Med. Trop. São Paulo, 53(1): 45-50, 2011.

In this context, it should also be emphasized the successful results by the use of the neotropical Cebus apella monkey (Primates: Cebidae) as experimental model for studying, in Brazil, the cutaneous leishmaniasis due to $L$. (V.) lainsoni, L. (V.) braziliensis and L. (L.) amazonensis ${ }^{23,24}$. This monkey species has also been incriminated as a wild reservoir of $L$. (V.) shawi in the Amazon region, Brazil, where this leishmanial parasite is considered an important agent of $\mathrm{ACL}^{8,25}$. Based in these findings, it was also investigated in vivo the susceptibility of $C$. apella monkey to experimental infection by $L$. (L.) $i$. chagasi, the etiological agent of AVL; the parasitological, clinical and immunological findings of this investigation are discussed in the present work.

\section{MATERIAL AND METHODS}

Local of experiment: This study was carried out in the Leishmaniasis Laboratory at the Parasitology Department of Evandro Chagas Institute (ECI, Ministry of Health, Brazil), in cooperation with the National Center of Primates (NCP, Ministry of Health, Brazil), both in Ananindeua municipality, Pará State, and the Pathology Laboratory of Infectious Diseases ("LIM-50"), Pathology Department, School of Medicine of the São Paulo University (“USP”), São Paulo State, Brazil.

Experimental animals: There were used ten (10) specimens, eight adult and two young, four males and six females, of the neotropical monkey $C$. apella (Primates: Cebidae), all born and raised in captivity from the National Center of Primates (NCP, Ministry of Health, Brazil), in good environmental and dietetic conditions.

Parasite: The L. (L.) i. chagasi-strain (MCAO/BR/2003/M22697/ Pará State) used in this experiment was provided by the Leishmaniasis Laboratory of Evandro Chagas Institute (ECI, Ministry of Health, Brazil), where the parasite is maintained into the criobank at temperature of $-180^{\circ} \mathrm{C}$.

Maintenance of $\boldsymbol{L}$. (L.) i. chagasi-strain virulence: In order to guarantee the continued virulence of $L$. (L.) $i$. chagasi-strain, the stationary phase promastigotes from Difco B45 blood-agar culture medium (WALTON et al. 1977)26 were re-inoculated, intra-peritoneal via, in laboratory hamster (Mesocricetus auratus).

\section{Inoculum preparation from stationary phase culture promastigotes:} Three months later, the amastigotes forms from the visceral infection of hamsters were transferred to the liquid culture medium RPMI-1640 (Sigma-Aldrich, USA) supplemented with $10 \%$ fetal bovine serum (FBS) (CULTILAS); $100 \mathrm{U} / \mathrm{mL}$ of penicillin-G; $100 \mu \mathrm{g} / \mathrm{mL}$ gentamicin; $2 \mathrm{mM}$ L-glutamine and $10 \mathrm{mM}$ hepes. The parasites were then cultivated at $25^{\circ} \mathrm{C}$ and the stationary phase promastigotes forms, established by way of a growth-curve, showed to be best used after seven days of culture. The final concentration of stationary phase promastigotes suspension was, approximately, $2 \times 10^{7} / \mathrm{mL}$ and the inoculum per animal was $0.1 \mathrm{~mL}$ ( $2 \times 10^{6}$ parasites).

Experimental infection protocol: There were carried out two experiments: i) in the first, six monkeys were inoculated, intra-dermal via (ID), into the base of the tail (at the dorsal surface) with $2 \times 10^{6} \mathrm{~L}$. (L.) $i$. chagasi-promastigotes forms from the stationary phase culture medium RPMI-1640; ii) in the second, other four monkeys were inoculated with, approximately, $3 \times 10^{7}$ amastigotes forms from the visceral infection of infected hamsters through two different via: a) two monkeys were inoculated by intravenous via (IV) and, b) other two by intra-peritoneal via (IP).

Evaluation parameters of experimental infection evolution: For all evaluations, the experimental monkeys were promptly anesthetized with an intramuscular injection of ketamine $(10 \mathrm{mg} / \mathrm{kg})$ plus xylazine $(1 \mathrm{mg} /$ $\mathrm{kg}$ ) solution (2:1 ratio) with the dose of $15 \mathrm{mg} / \mathrm{kg}^{7,13}$. The experimental infection evaluations of monkeys were at monthly intervals and included the following criteria:

1) Clinical: physical evaluation of the abdomen, the weight and the body temperature;

2) Specific laboratory: needle aspiration of the bone-marrow (Fig. 1) for the parasitological searching of amastigotes forms in Giemsa-stained smears, and promastigotes forms in the blood-agar culture medium Difco B $45^{26}$;

3) Specific immune response: a) Indirect fluorescence antibody test (IFAT) ${ }^{10,21,22}$ with a specific anti-monkey conjugate (Bethyl, USA) looking for the specific IgG-antibody response; and, b) Delayed-type hypersensitivity $(\mathrm{DTH})^{18,21,22}$ with a homologous $L$. (L.) i. chagasipromastigotes antigen $\left(10^{6}\right.$ parasites/intra-dermal dose), searching for the T-cell immune response. However, considering some speculation on the capacity of DTH-skin reaction in producing immunogenic effect in the receptors ${ }^{11}$, this assay was only realized once time, at the end $\left(11^{\text {th }}\right.$ month) of the period of experimental infection evaluation.

Control of the experimental infections: As a control of each experimental infection in $C$. apella monkey, there was used the same type of inoculum, such as, $2 \times 10^{6}$ promastigotes forms or 3 x $10^{7}$ amastigotes forms of $L$. (L.) $i$. chagasi, for inoculating, by intraperitoneal via, into two hamsters (each type of inoculum) that were followed-up till three to four months post-inoculation for the developing of visceral infection.

Data analysis: The statistically significant differences on the criteria used for evaluating the susceptibility of $C$. apella to experimental $L$. (L.) $i$. chagasi-infection were obtained by the use of the Bio-Estat 4.0 software $^{2}$. The $\mathrm{X}^{2}$ was used to compare these differences with $p<0.05$ considered to be as significant.

Ethical approval: This study was approved by the Ethics Committee in Animal Research of Evandro Chagas Institute (ECI), Surveillance Secretary of Health, Ministry of Health, Brazil, with the protocol number 10/2004 (CEPAN/IEC/SVS/MS/Brazil).

\section{RESULTS}

In the six $C$. apella monkeys ID inoculated into the base of the tail with $2 \times 10^{6}$ promastigotes forms (stationary phase) of L. (L.) i. chagasi there was not observed till the $12^{\text {th }}$ month pos inoculation (p.i.) any clinical sign which could be related to the active infection (symptomatic) in these monkeys, as well as there were not found neither amastigotes forms in the Giemsa-stained smears nor promastigotes forms in the blood-agar culture medium (Difco B45) of the parasite from the bone-marrow. Besides this, there were not demonstrated in none of these monkeys neither the development of the humoral immune response characterized 


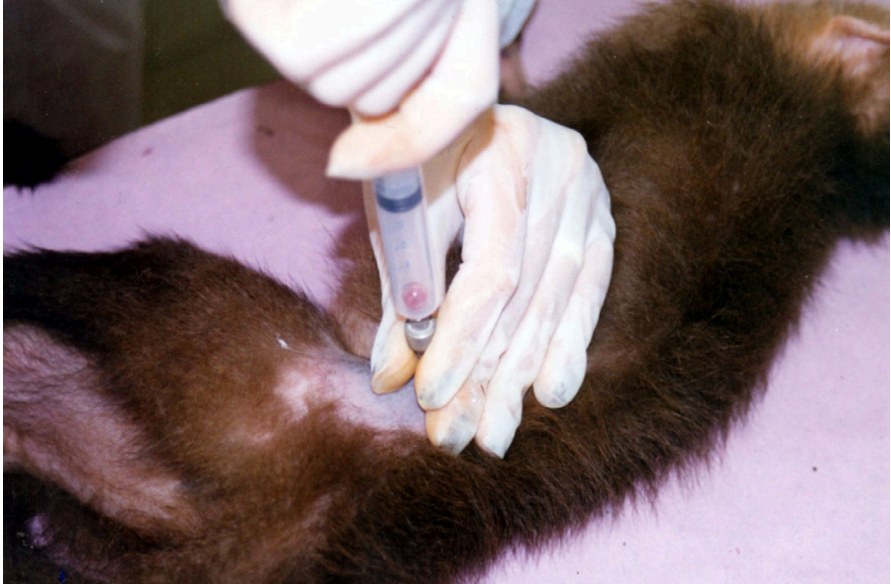

Fig. 1 - The needle aspiration proceeding of the bone-marrow from a specimen of C. apella monkey, following anesthesia.
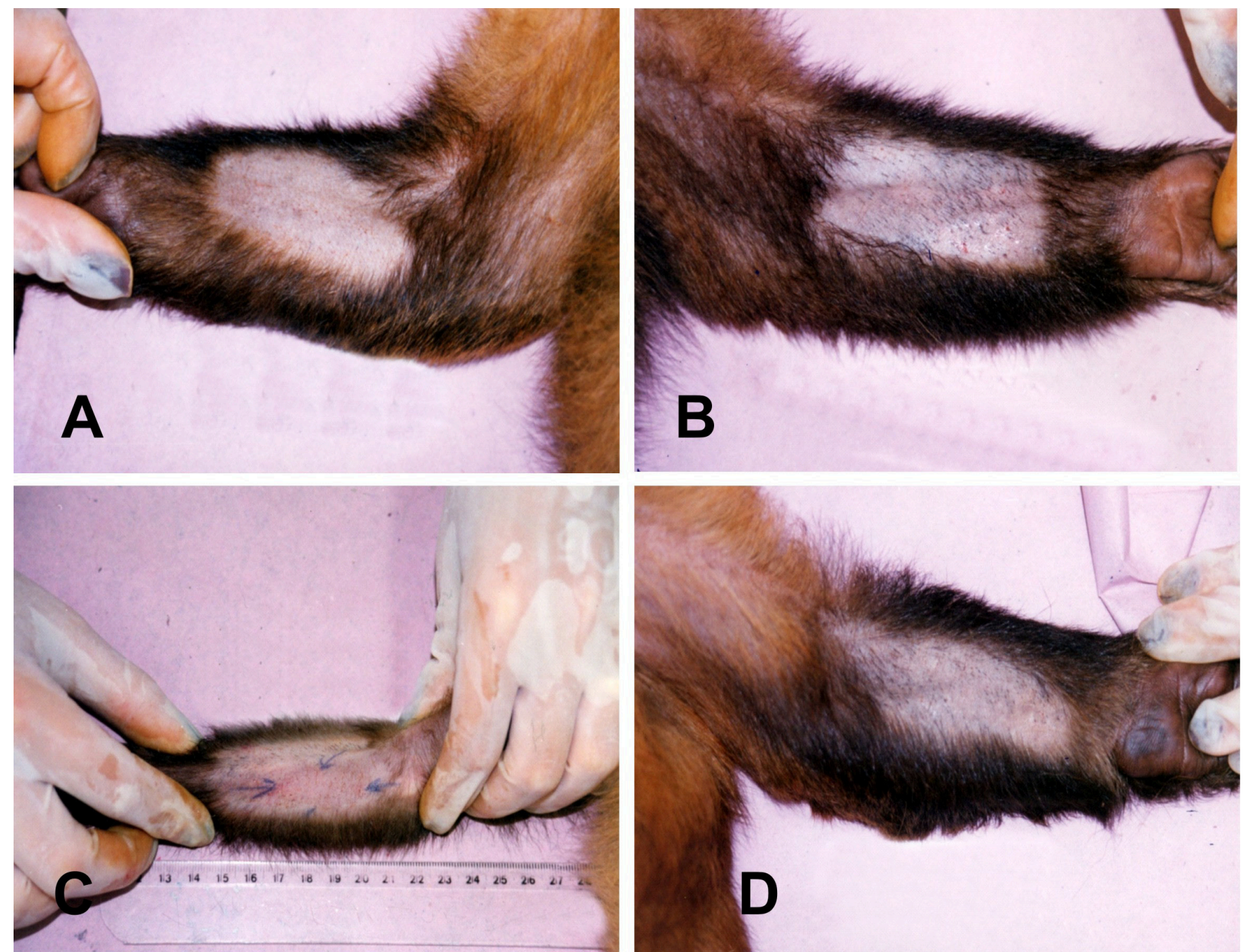

by the specific IgG-antibody response (IFAT) against to $L$. (L.) i. chagasi, nor the DTH-skin reaction (specific T-cell immune response) (Fig. 2).

On the other side, concerning those four $C$. apella monkeys inoculated with $3 \times 10^{7}$ amastigotes forms (from the visceral infection of hamsters) of $L .(L)$.$i . chagasi it was observed, till 12^{\text {th }}$ month p.i., in the two monkeys, IV inoculated, a significant mean weight decrease of $501 \mathrm{gr}$ in relation to other two monkeys, IP inoculated, which presented a weight decrease of only $258 \mathrm{gr}$. In relation to the body temperature, there was not found any difference on the mean temperature $\left(38.5^{\circ} \mathrm{C}\right)$ regarding these two monkeys groups (IV x IP).

As far as the parasitological research is concerned, it was demonstrated the presence of $L$. ( $L$.) $i$. chagasi from the bone-marrow either in the Giemsa-stained smears (amastigotes forms) or in the blood-agar culture medium Difco B45 (promastigotes forms) since the first toward to the $6^{\text {th }}$ month $p . i$. in the two monkeys IV inoculated; from the seven toward to the $12^{\text {th }}$ month $p . i$. there was the clearance of

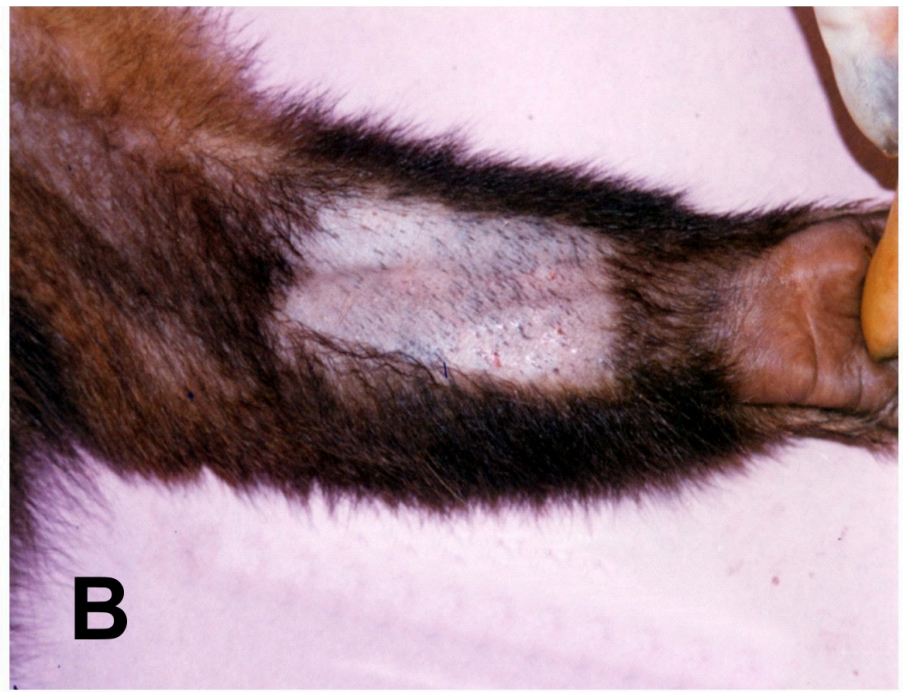

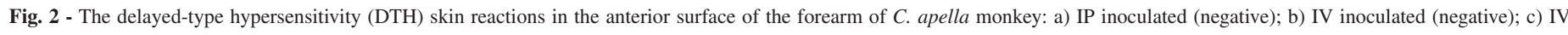
inoculated $(30 \mathrm{~mm}$ skin infiltration $=$ positive $)$; and, d) control negative. 


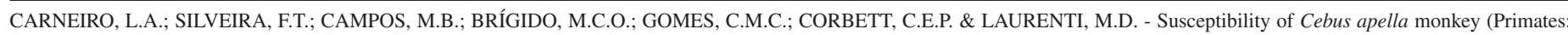
Cebidae) to experimental Leishmania (L.) infantum chagasi-infection. Rev. Inst. Med. Trop. São Paulo, 53(1): 45-50, 2011.

the parasite in the bone-marrow of these two monkeys. On the other hand, in the two monkeys IP inoculated the parasitological research was totally negative.

Regarding the specific IgG-antibody response (IFAT), it was demonstrated the seroconversion of all four monkeys inoculated with amastigotes forms since the third month $p . i$., with 1/80 for the monkeys IP inoculated, and 1/320 for the monkeys IV inoculated. The evolution of the IgG-antibody response showed, in the two monkeys IP inoculated, an increase to $1 / 320$ at the $5^{\text {th }}$ month p.i.; following this, the IgG-antibody response came down to $1 / 160$ at the $6^{\text {th }}$ month $p . i$. and remained in this level $(1 / 160)$ till the last month $\left(12^{\text {th }}\right)$ of evaluation. On the other hand, in the two monkeys IV inoculated there was a progressive increase in the IgG-antibody response toward to the $11^{\text {th }}$ month p.i. going up to $1 / 5,120$ and keeping in this level till the $12^{\text {th }}$ month p.i.

As it was prior concerned, the DTH-skin reaction was only realized at the $11^{\text {th }}$ month $p . i$. and regarding the two monkeys IP inoculated this revealed results totally negative; in the case, however, of the two monkeys IV inoculated, one was also negative whereas the other showed a very strong response (30 $\mathrm{mm}$ of skin infiltration) in comparison with the negative control (Fig. 2).

At last, it must also be confirmed that all four hamsters (two equal groups) used as control animal for the experimental infections in C. apella monkey with $L$. (L.) $i$. chagasi have developed visceralizing infection following IP inoculation with the two types of inoculum used in the monkeys, as follows; the first group inoculated with $2 \times 10^{6}$ stationary phase promastigotes forms have developed clinical signs of disease after 3 to 4 months p.i.; the second group inoculated with $3 \times 10^{7}$ amastigotes forms have developed clinical signs of disease after two months p.i., confirming the infectivity of these inoculum.

\section{DISCUSSION}

The use of non-human primates as animal model for studying the visceral leishmaniasis has been the target of many studies either in the Old World or in the New World, aiming to establish an experimental biological system which may evaluate the clinical and immunopathological events inherent to the process of interaction between the pathogenic viscerotropic leishmanial parasites (L. donovani, $L$. infantum and $L$. $i$. chagasi) and the humoral and T-cell immune responses of man. However, although some works have successfully documented the use of a given monkey species, it has been noted that in most situations the successful result was only achieved following the use of an exaggerated inoculum of either amastigotes or promastigotes forms of one of these pathogenic viscerotropic Leishmania spp., which characterizes an experimental approach excessively artificial and, consequently, rather different from the natural transmission of disease by phlebotomine sand fly.

In this way, it should be highlighted the work of GICHERU et $a l .{ }^{6}$ which used $8 \times 10^{7}$ promastigotes forms of $L$. (L.) donovani to experimentally infect, by intra-dermal via, the African green monkey, Cercopithecus aethiops. In this experiment, from nine monkeys inoculated with this parasite, four developed clinical manifestations of visceral leishmanisis and have died following eighteen months $p . i$. Regarding yet the visceral leishmaniasis of the Old World, BINHAZIM ${ }^{3}$ have also challenged the African green monkey, C. aethiops, with $10^{7}$ amastigotes forms $/ \mathrm{kg}$ of weight, by IV via, of $L$. (L.) donovani and $L$. (L.) infantum. As a result, these authors have observed several clinical manifestations similar to that of man, as well as some hematological disorders and the development of a specific IgG-antibody response. Other example concerning the use of non-human primates as animal model for studying the Old World visceral leishmaniasis was that of ANURADHA ${ }^{1}$, which used the Indian monkey, Presbytis entellus, for experimental infecting it with $10^{8}$ amastigotes forms of $L$. (L.) donovani, by IV via. The clinical and immunological results of this experiment have encouraged these authors to consider the Indian monkey, P. entellus, as a promising animal model for studying the Old World visceral leishmaniasis due to L. (L.) donovani. Nevertheless, as prior reported, these relative successful findings were only achieved by the use of a high inoculum of amastigotes or promastigotes forms of these pathogenic viscerotropic parasites, as well as the artificial IP or IV ways for inoculation of these parasites, characterizing these experiments as much artificial.

With respect to the experiments regarding $L$. (L.) $i$. chagasi, the etiologic agent of New World visceral leishmaniasis, it should be emphasized the pioneer work of MARSDEN et al. ${ }^{12}$ whom inoculated, by IV via, a pool of the liver and spleen (amastigotes forms) of infected hamsters in the neotropical monkey Callithrix jacchus. In that year, CHAPMAN \& HANSON ${ }^{5}$ have also used the IV via for developing the experimental infection of the neotropical monkey Saimiri sciureus with an inoculum of approximately $3 \times 10^{7}$ amastigotes forms of $L$. (L.) i. chagasi. Lastly, BRODERSON et al. ${ }^{4}$ have studied the susceptibility of the monkey Aotus trivirgatus (= Aotus infulatus) to experimental infection due to $L$. (L.) i. chagasi by inoculating, IV via, approximately, $32.5 \times 10^{6}$ amastigotes forms of the parasite in eight specimens of this monkey; following three months p.i. six monkeys have died and two have survived from the visceral infection.

With basis on the above comments, it seems reasonable to speculate that susceptibility of a given monkey species to these pathogenic viscerotropic leishmanial parasites would be best analyzed by using an experimental infection protocol with intra-dermal inoculation of promastigotes forms of these parasites with a concentration not too high like those used in the works discussed above. In this way, regarding that in the present work there were used two infection protocols, one with promastigotes forms ID inoculated and, another with amastigotes forms IP and IV inoculated, then the results will be discussed separately. First, with respect to the experimental infection realized with intra-dermal inoculation of promastigotes forms of $L$. (L.) $i$. chagasi, it should be emphasized that the suspension concentration of the parasite $\left(2 \times 10^{7}\right)$ was equivalent to those successfully used in prior studies with the same monkey species, $C$. apella, for studying the development of experimental cutaneous leishmaniasis by $L$. (V.) braziliensis, $L$. (V.) lainsoni and $L$. (L.) amazonensi s $^{23,24}$. Thus, considering that this experimental infection protocol has prior promoted satisfactory results with dermotropic Leishmania spp. in the C. apella monkey, it is believed that the present findings with promastigotes forms of $L$. (L.) $i$. chagasi, which revealed totally negative in terms of clinical, parasitological and immmunological evaluation parameters, should likely be credited to a natural resistance of $C$. apella monkey against to experimental $L$. (L.) i. chagasi-infection.

Second, with regards to the experiments carried out with IP and IV inoculation of $3 \times 10^{7}$ amastigotes forms of $L$. (L.) $i$. chagasi, the results obtained have shown that this inoculum concentration was incapable 
CARNEIRO, L.A.; SILVEIRA, F.T.; CAMPOS, M.B.; BRÍGIDO, M.C.O.; GOMES, C.M.C.; CORBETT, C.E.P. \& LAURENTI, M.D. - Susceptibility of Cebus apella monkey (Primates: Cebidae) to experimental Leishmania (L.) infantum chagasi-infection. Rev. Inst. Med. Trop. São Paulo, 53(1): 45-50, 2011.

of promoting a patent experimental infection in the $C$. apella monkey when this inoculum was IP injected. Otherwise, when the inoculum was IV injected, it was confirmed the patent infection in the bonemarrow of the two monkeys by demonstrating the amastigotes forms of the parasite in Giemsa-stained smears, as well as the promastigotes forms in the blood-agar culture medium B $45^{26}$, since the first toward to the $6^{\text {th }}$ month p.i. Following this time point $\left(6^{\text {th }}\right.$ month p.i.), it was not possible to demonstrate the bone-marrow infection till the end of the experiment follow-up ( $12^{\text {th }}$ month p.i.), revealing that the two C. apella monkeys were capable to promote the clearance of infection from the bone-marrow. Besides this, there were not detected neither clinical sign (hepatosplenomegaly) nor symptom (fever) that could suggest the presence of active infection in the monkeys, even in the presence of a progressive IgG-antibody response against to $L$. $(L$.) $i$. chagasi, which raised up to 5,120 at the $12^{\text {th }}$ month p.i. Supporting this idea, it was confirmed in one of the two monkeys IV inoculated a very strong DTHskin reaction (30 $\mathrm{mm}$ diameter), characterizing the development of T-cell immune response against to $L$. $(L$.) $i$. chagasi-infection, which represents one of major resistance immunological mechanisms.

Taking all these comments in account, it is believed that $C$. apella monkey might have a resistant natural T-cell immune mechanism against to $L$. (L.) i. chagasi-infection, once even the two monkeys IV inoculated with $3 \times 10^{7}$ amastigotes forms of $L$. (L.) $i$. chagasi have developed temporary infection of the bone-marrow, they were capable of promoting the clearance of infection, clearly demonstrating the ability of inhibiting the $L$. (L.) $i$. chagasi-growth into the macrophage; thus, contradicting the use of $C$. apella monkey as a suitable animal model for studying AVL.

\section{FOUNDING}

This work was supported by the Instituto Evandro Chagas (Secretaria de Vigilância em Saúde, Ministério da Saúde, Brazil); Instituto de Medicina Tropical (Universidade Federal do Pará, Brazil); Laboratório de Investigação Médica (LIM)-50 (Hospital das Clínicas (HC)-Faculdade de Medicina (FM)-Universidade de São Paulo (USP), Brazil) and, Fundação de Amparo à Pesquisa do Estado de São Paulo (FAPESP: 06/56319-1, Brazil).

\section{CONFLICT OF INTEREST STATEMENT}

There are no conflicts of interest.

\section{RESUMO}

\section{Susceptibilidade do macaco Cebus apella (Primata: Cebidae) à infecção experimental por Leishmania (L.) infantum chagasi}

Na Amazônia Brasileira, o macaco Cebus apella (Primata: Cebidae) tem sido associado com o ciclo enzoótico da Leishmania (V.) shawi, um parasito dermotrópico causador da Leishmaniose Tegumentar Americana (LTA). Ele tem sido também empregado com sucesso como modelo experimental para estudo da leishmaniose tegumentar. Neste trabalho, foi investigada sua susceptibilidade à infecção experimental por Leishmania (L.) infantum chagasi, o agente etiológico da Leishmaniose Visceral Americana (LVA). Foram usados dez espécimes de $C$. apella oito adultos e dois jovens, quatro machos e seis fêmeas, todos nascidos e criados em cativeiro. Dois protocolos de infecção experimental foram feitos: i) seis macacos foram inoculados por via intradérmica (ID), na base da cauda $\operatorname{com} 2 \times 10^{6}$ formas promastigotas em fase estacionária de crescimento; ii) outros quatro macacos foram inoculados com $3 \times 10^{7}$ formas amastigotas de infecção visceral de hamsteres por duas vias diferentes: a) dois por via intravenosa (IV) e, b) outros dois pela via intraperitoneal (IP). A avaliação da infecção incluiu parâmetros: clínico: exame físico do abdômen, peso e temperatura corporal; b) parasitológico: aspirado de medula óssea por agulha para procura de amastigotas (esfregaço corado por Giemsa) e formas promastigotas (meio de cultura); c) imunológico: Reação de Imunofluorescência Indireta (RIFI) e, resposta de hipersensibilidade tardia (DTH). Nos seis macacos inoculados ID (formas promastigotas) todos os parâmetros de avaliação da infecção foram negativos durante o período de 12 meses. Entre os quatro macacos inoculados com formas amastigotas, dois inoculados IV mostraram parasitos na medula óssea do primeiro ao sexto mês $p$. i. e em seguida houve a resolução da infecção, no entanto os outros dois inoculados IP foram totalmente negativos. Esses quatro macacos apresentaram resposta específica de anticorpo IgG desde o terceiro mês p.i. (IP: 1/80 e IV: 1/320) até o décimo segundo mês (IP: 1/160 e IV: 1/5120). A conversão DTH ocorreu em apenas um macaco inoculado IV com uma forte reação na pele $(30 \mathrm{~mm})$. Considerando esses resultados, nós não recomendamos o uso do macaco $C$. apella como modelo animal para estudo da LVA.

\section{REFERENCES}

1. Anuradha PR. The Indian langur: preliminary report of a new nonhuman primate host for visceral leishmaniasis. Bull World Health Organ. 1992;70:63-72.

2. Ayres M, Ayres Jr M, Ayres D, Santos AS. Bioestat 4.0: aplicações estatísticas nas áreas das ciências biológicas e médicas. Belém: Sociedade Civil Mamirauá; 2005.

3. Binhazim AA. Comparative susceptibility of African green monkey (Cercopithecus aethiops) to experimental infection with Leishmania (L.) donovani and Leishmania (L.) infantum. Lab Anim Sci. 1993;43:37-47.

4. Broderson JR, Chapman WL Jr, Hanson WL. Experimental visceral leishmaniasis in the owl monkey. Vet Pathol. 1986;23:293-302.

5. Chapman WL Jr, Hanson WL. Visceral leishmaniasis in the squirrel monkey (Saimiri sciurea). J Parasitol. 1981;67:740-1.

6. Gicheru MM, Olobo JO, Kariuki TM, Adhiambo C. Visceral leishmaniasis in vervet monkeys: immunological responses during asymptomatic infections. Scand J Immunol. 1995;41:202-8.

7. King A. Anesthesia of capuchin monkeys. Vet Rec. 1994;134:559.

8. Lainson R, Braga RR, Souza AAA, Póvoa MM, Ishikawa EAI, Silveira FT. Leishmania (Viannia) shawi sp. n., a parasite from monkeys, sloths and procyonids in Amazonian Brazil. Ann Parasitol Hum Comp. 1989;64:200-7.

9. Lainson R, Shaw J.J. Leishmaniasis in the New World. In: Collier L, Balows A, Sussman M, editors: Topley \& Wilson's Microbioly and microbial infections. $10^{\text {th }} \mathrm{ed}$. London: Arnold; 2005. v.5, Parasitology, p. 313-49.

10. Lima LVR, Souza AAA, Jennings YL, Corrêa Z, Jesus R, Everdosa D, et al. Comparison of the reactivity between antigens of Leishmania (L.) chagasi, L. (L.) amazonensis and Leishmania sp. (Bio-Manguinhos) in the sero-diagnosis of visceral leishmaniasis by the indirect fluorescent antibody test (IFAT). Rev Inst Med Trop Sao Paulo. 2003;45(Suppl 13):147.

11. De Luca PM, Mayrink W, Santiago MA, Nogueira R, Conceição-Silva F, Melo G, et al. Randomized, double-blind, placebo-controlled study on the immunogenicity of the leishmanin skin test. Trans R Soc Trop Med Hyg. 2003;97:709-12. 
CARNEIRO, L.A.; SILVEIRA, F.T.; CAMPOS, M.B.; BRÍGIDO, M.C.O.; GOMES, C.M.C.; CORBETT, C.E.P. \& LAURENTI, M.D. - Susceptibility of Cebus apella monkey (Primates: Cebidae) to experimental Leishmania (L.) infantum chagasi-infection. Rev. Inst. Med. Trop. São Paulo, 53(1): 45-50, 2011.

12. Marsden PD, Cuba CC, Vexenat A, Costa e Silva M, Costa e Silva A, Barreto AC. Experimental Leishmania chagasi infections in the marmoset Callithrix jacchus jacchus. Trans R Soc Trop Med Hyg. 1981;75:314-5.

13. Massone F. Anestesiologia veterinária: farmacologias e técnicas. $4^{\mathrm{a}}$ ed. Rio de Janeiro: Guanabara Koogan; 2003.

14. Misra A, Dube A, Naik S. Immune responses in normal Indian langur monkeys (Presbytes entellus); a primate model for visceral leishmaniasis. J Med Primatol. 2004;33:65-9.

15. Misra A, Dube A, Srivastava, JK, Sharma P, Katiyar JC, Naik S. Establishment of asymptomatic Leishmania donovani infection in Indian langurs (Presbytis entellus) through intradermal route. Indian J Exp Biol. 2002;40:605-8.

16. Misra A, Dube A, Srivastava B, Sharma P, Srivastava JK, Katyiar JC, et al. Successful vaccination against Leishmania donovani infection in Indian langur using alumprecipitated autoclaved Leishmania major with BCG. Vaccine. 2001;19:3485-92.

17. Olobo JO, Gicheru MM, Anjili CO. The African Green Monkey model for cutaneous and visceral leishmaniasis. Trends Parasitol. 2001;17:588-92.

18. Silveira FT, Blackwell JM, Ishikawa EA, Braga RR, Shaw JJ Quinnell RJ, et al. T cell responses to crude and defined leishmanial antigens in patients from the lower Amazon region of Brazil infected with different species of Leishmania of the subgenera Leishmania and Viannia. Parasite Immunol. 1998;20:19-26.

19. Silveira FT, Corbett CEP. Leishmania chagasi Cunha \& Chagas, 1937: indigenous or introduced? A brief review. Rev Pan-Amaz Saude. 2010;1:143-7.

20. Silveira FT, Ishikawa EAI, Souza AAA, Lainson R. An outbreak of cutaneous leishmaniasis among soldiers in Belém, Pará State, Brazil caused by Leishmania (Viannia) lindenbergi $\mathrm{n}$. sp., a new leishmanial parasite of man in the Amazon region. Parasite. 2002;9:43-50.
21. Silveira FT, Lainson R., Souza AAA, Crescente JAB, Campos MB, Gomes CMC, et al. A prospective study on the dynamics of clinical and immunological evolution of human Leishmania (L.) infantum chagasi infection in the Brazilian Amazon region. Trans R Soc Trop Med Hyg. 2010;104:529-35.

22. Silveira FT, Lainson R, Pereira EA, Souza AAA, Campos MB, Chagas EJ, et al. A longitudinal study on the transmission dynamics of human Leishmania (Leishmania) infantum chagasi infection in Amazonian Brazil, with special reference to its prevalence and incidence. Parasitol Res. 2009;104:559-67.

23. Silveira FT, Lainson R, Shaw JJ, Garcez LM, Souza AAA, Braga R, et al. Leishmaniose cutânea experimental. II. Aspectos evolutivos da infecção no primata Cebus apella (Cebidae) pela Leishmania (V.) braziliensis e L. (L.) amazonensis. Rev Soc Bras Med Trop. 1990;23:5-12.

24. Silveira FT, Moraes MAP, Lainson R, Shaw JJ. Leishmaniose cutânea experimental. III Aspectos histopatológicos do comportamento evolutivo da lesão cutânea produzida em Cebus apella (Primates: Cebidae) por Leishmania (V.) lainsoni, L. (V.) braziliensis e L. (L.) amazonensis. Rev Inst Med Trop Sao Paulo. 1990;32:387-94.

25. Silveira FT, Shaw JJ, Bichara CNC, Costa JML. Leishmaniose visceral americana. In Leão RNG. Doenças infecciosas e parasitárias: enfoque Amazônico. Belém: CEJUP; 1997. p. 631-44.

26. Walton BC, Shaw JJ, Lainson R. Observations on the in vitro cultivation of Leishmania braziliensis. J Parasitol. 1977;63:1118-9.

Received: 16 August 2010

Accepted: 28 October 2010 